\title{
Porcine placenta hydrolysates regulate calcium disturbance in MC3T3-E1 osteoblastic cells
}

\author{
Hwa-Young Lee ${ }^{1}$, Hyung-Ryong Kim², Sun-Young Park ${ }^{3}$, Han-Jung Chae ${ }^{1}$ and Jong-Hyun Kim ${ }^{4}$
}

\begin{abstract}
Background: In bone metabolism, $\mathrm{Ca}^{2+}$ disturbance and oxidative damage are the main biochemical factors related to pathology. Osteoblasts are bone-forming cells that also control bone endocrinology. Endocrine hormones and proteins are matured, folded, and secreted in the endoplasmic reticulum (ER). ER stress has emerged as a new pathological mechanism to explain bone disturbance. Here we studied the role of porcine placenta hydrolysates (PPHs) in the regulation of ER stress.

Methods: Cell viability was determined in vitro using trypan blue dye exclusion. ER stress and apoptosis were evaluated using immunoblotting and a caspase kit. The fluorescent $\mathrm{Ca}^{2+}$-binding dye Fura-2/AM was used to measure changes in intracellular $\mathrm{Ca}^{2+}\left(\left[\mathrm{Ca}^{2+}\right]_{\mathrm{i}}\right)$. ROS levels, NADPH oxidase activity, and superoxide dismutase (SOD) activity were also measured.

Results: PPHs protected MC3T3-E1 osteoblastic cells against thapsigargin (Tg)-induced ER stress. Moreover, PPHs regulated caspase-12 and -3 activities, thereby protecting against cell death, and also regulated Tg-induced $\mathrm{Ca}^{2+}$ release. The $\mathrm{Ca}^{2+}$ chelator BAPT/AM also regulated caspase-12 and -3 activities and prevented $\mathrm{Ca}^{2}$ stress-induced cell death. In the presence of PPHs or BAPTA/AM, $\mathrm{Ca}^{2+}$-related ROS were also regulated, as demonstrated by alterations in NADPH oxidase and SOD activity.
\end{abstract}

Conclusions: PPHs appear to regulate bone metabolism disturbance by controlling $\mathrm{Ca}^{2+}$ concentrations, and thus ER stress and ROS, in osteoblasts cultured in vitro.

Keywords: Osteoporosis, Oxidative damage, Calcium, Porcine placenta hydrolysates, ER stress

\section{Background}

Osteoporosis is characterized by decreased bone strength, decreased bone mass, and deterioration of bone tissue. An imbalance between bone resorption and bone formation is the dominant mechanism causing osteoporosis $[1,2]$. Since new bone formation primarily depends on osteoblasts, factors that disturb their bone-forming characteristics can lead to bone formation defects or related pathological conditions. Osteoblasts are secretory cells with well-developed endoplasmic reticulum (ER) cristae. The balance of osteoblasts and osteoclastic cells is carefully controlled [1, 3, 4]. During severe pathologic stress, apoptosis occurs in

\footnotetext{
* Correspondence: obgyn2001@naver.com

${ }^{4}$ Department of Obstetrics and Gynecology, Institute for Medical Sciences, Chonbuk National University Medical School, Jeonju 560-182, Republic of Korea

Full list of author information is available at the end of the article
}

osteoblasts, which disturbs the balance between osteoblasts and osteoclasts and ultimately leads to bone resorption and related disease conditions [5].

The ER plays a major role in controlling protein folding and secretion in cells. Various acute and chronic conditions, including misfolded proteins and $\mathrm{Ca}^{2+}$ disturbances, can alter ER function and lead to ER stress [6-8]. $\mathrm{Ca}^{2+}$ disturbance and oxidative stress (which is related to $\mathrm{Ca}^{2+}$ disturbance) have been suggested to lead to pathological ER stress. Furthermore, ER stress has been reported to contribute to several diseases, including bone diseases $[9,10]$. Osteoblast apoptosis associated with ER stress is one of the predominant mechanisms of osteoporosis pathogenesis [11-14]. In stressed osteoblasts, endocrine function, including the production of bone formation hormones (e.g., osteopontin and osteocalcin), is damaged $[15,16]$. During 
severe ER stress, apoptosis is also induced [17-19]. Consequently, ER stress regulators are of great importance in bone-related endocrine cells.

The placenta is an organ found exclusively in women during pregnancy that supplies nutrients and oxygen to the developing fetus. The nutritional substances and vitamins therein can be extracted in the form of porcine placenta hydrolysates (PPHs). PPHs are considered to be a reservoir of cytokines, hormones, bioactive peptides, enzymes, growth factors, and minerals [20]. PPHs also contain valuable bioactive compounds that have various biological functions, including inhibiting aging, inflammation, sunburn, gene mutation, and oxidation [21]. PPHs have been used for wound healing in Korean folk medicine $[22,23]$ and have been demonstrated to have immunomodulatory effects in various studies $[24,25]$. Moreover, PPHs have been used in cosmetic and pharmaceutical products for whitening and oxidative stress-induced diseases, respectively [20]. However, the effect of PPHs on bone-related endocrine cells, including osteoblasts, has received comparatively little attention. To determine the role of PPHs in the endocrine system, it is important to determine the effects of PPHs on osteoblasts, a representative endocrine cell associated with stress conditions.

We based our study on the knowledge that osteoblasts are susceptible to $\mathrm{Ca}^{2+}$ disturbance and hypothesized that they amplify their signaling to closely related cells. Thus, in this pharmacological study of PPHs, we studied $\mathrm{Ca}^{2+}$ disturbance in the context of related ER stress and cell death. We tested the hypothesis that PPHs regulate ER stress by affecting $\mathrm{Ca}^{2+}$ homeostasis, leading to cell protection. Our results indicate that PPHs are a novel group of ER stress regulators, at least in bone-forming osteoblasts, with an additional protective role against $\mathrm{Ca}^{2+}$ disturbance.

\section{Methods \\ Materials}

PPHs were obtained from Codebio Inc. (Cheonan, Republic of Korea). Hydrogen peroxide and thapsigargin were obtained from Sigma Chemical Company (St. Louis, MO, USA). BAPTA/AM was purchased from Invitrogen (Carlsbad, CA, USA). Caspase- 3 and -12 activity kits were obtained from BioVision (Mountain View, CA, USA). All other chemicals and reagents used in this study were of reagent-grade quality and were obtained commercially.

\section{Cell culture and viability analysis}

The MC3T3-E1 osteoblast-like cell line (mouse C57BL/6 calvaria, subclone 4, ATCC No. 58078614) was purchased from the American Type Culture Collection (ATCC; Manassas, VA, USA). MC3T3-E1 osteoblastic cells were cultured in minimum essential medium ( $\alpha$ MEM) supplemented with $10 \%$ fetal bovine serum (FBS), $100 \mathrm{U} / \mathrm{mL}$ penicillin, and $100 \mu \mathrm{g} / \mathrm{mL}$ streptomycin (Gibco). Cells were maintained at $37{ }^{\circ} \mathrm{C}$ in a humidified atmosphere of $5 \% \mathrm{CO}_{2}$. After the cells were cultured with $\mathrm{PPHs}$ and/or other agents, cell viability was assessed by trypan blue dye exclusion using a hemocytometer.

\section{Quantification of apoptosis}

To visualize nuclear morphology, cells were fixed in $4 \%$ paraformaldehyde and stained with $2.5 \mu \mathrm{g} / \mathrm{ml}$ Hoechst 33342 DNA dye. Cells with uniformly stained nuclei were scored as healthy and viable. Cells with condensed or fragmented nuclei were scored as apoptotic. To ensure that the counting was unbiased, all petri dishes were coded before the cells were scored. Separately, the apoptosis assay using flow cytometry was performed according to the vendor's protocol (BD Pharmingen, BD Biosciences, San Jose, USA). Briefly, the cells were treated with $0.1 \mu \mathrm{M} \mathrm{Tg}$ at $37{ }^{\circ} \mathrm{C}$ in the presence or absence of $100 \mu \mathrm{g} / \mathrm{mL}$ PPHs or $2 \mu \mathrm{M}$ BAPTA/AM for $24 \mathrm{~h}$ and were trypsinized, washed in PBS and resuspended $\left(1 \times 10^{6}\right.$ cells $\left./ \mathrm{ml}\right)$ in binding buffer $(10 \mathrm{mM}$ HEPES, pH 7.4, $140 \mathrm{mM} \mathrm{NaCl}, 2.5 \mathrm{mM} \mathrm{CaCl}_{2}$ ). A fraction $\left(100 \mu \mathrm{l} / 1 \times 10^{5}\right.$ cells $)$ of the cell suspension was incubated with $5 \mu \mathrm{l}$ Annexin $\mathrm{V}$ conjugated to FITC and $5 \mu \mathrm{l}$ propidium iodide (PI) for 15 mins at $25^{\circ} \mathrm{C}$ in the dark. $400 \mu \mathrm{l}$ of binding buffer was added to the suspension and apoptosis was measured immediately using a BD FACSCalibur flow cytometry (BD Biosciences, Franklin Lakes, NJ, USA).

\section{Immunoblotting}

For immunoblotting, MC3T3-E1 osteoblastic cells were lysed by the addition of lysis buffer [ $50 \mathrm{mM}$ Tris- $\mathrm{HCl}$ (pH 7.4), $150 \mathrm{mM} \mathrm{NaCl}, 0.25 \%$ sodium deoxycholate, $1 \%$ NP-40, $1 \mathrm{mM}$ ethylenediaminetetraacetic acid (EDTA), $0.1 \%$ sodium dodecyl sulfate (SDS), protease inhibitor cocktail set III (EMD Biosciences, La Jolla, CA, USA) and phosphatase inhibitor cocktail set II (EMD Biosciences)] directly onto the cells. The proteins in the lysates $(40 \mu \mathrm{g})$ were resolved on polyacrylamide gels and transferred to nitrocellulose membranes that were then blocked with skim milk for $1 \mathrm{~h}$ at room temperature. The blots were probed overnight at $4{ }^{\circ} \mathrm{C}$ with the appropriate primary antibodies, washed, and probed again with species-specific secondary antibodies coupled to horseradish peroxidase (GE Healthcare, Piscataway, NJ, USA). Chemiluminescence reagents (GE Healthcare) were used for signal detection. Primary antibodies included rat anti-GRP78, rabbit anti-GADD153/ C/EBP homologous protein (CHOP), rabbit-anti-PERK, mouse anti-eIF2 $\alpha$, rabbit anti-ATF6 $\alpha$, and mouse anti- $\beta$ actin (Santa Cruz Biotechnologies, Inc., Santa Cruz, CA, USA), in addition to rabbit anti-phospho-eIF2 and rabbit 
anti-IRE1 $\alpha$ (Cell Signaling Technologies, Inc., Danvers, MA, USA).

\section{Calcium analysis}

The procedures for $\mathrm{Ca}^{2+}$ measurements were modified from Kim et al. [26]. Briefly, the low affinity fluorescent $\mathrm{Ca}^{2+}$ dye Fura-2/AM (1-[2-(5-carboxyoxazol-2-yl)-6-aminobenzoFURAn-5-oxy]-2-(2-amino-5methylphenoxy)-ethane- $N, N, N, N^{\prime}$-tetraacetic acid pentaacetoxymethyl ester; Molecular Probes, Eugene, OR, USA) was used to measure changes in intracellular $\mathrm{Ca}^{2+}$ $\left(\left[\mathrm{Ca}^{2+}\right]_{i}\right)$. Cells were incubated with Fura-2/AM $(2 \mu \mathrm{M})$ for 30 min at room temperature in Hanks' balanced salt solution. After loading, cells were washed three times in isotonic buffer without $\mathrm{Ca}^{2+}$ (KH buffer: $132 \mathrm{mM} \mathrm{NaCl}$, $5 \mathrm{mM} \mathrm{KCl}, 10 \mathrm{mM}$ glucose, $10 \mathrm{mM}$ HEPES, and $1.05 \mathrm{mM}$ $\mathrm{MgCl}_{2}$ ). Cells were then promptly treated with thapsigargin. Changes in $\left[\mathrm{Ca}^{2+}\right]_{i}$ were determined by measuring the ratio of 340/380 $\mathrm{nm}$ excitation (512 nm emission) using an integrated spectrofluorometer (Photon Technology International, Birmingham, NJ, USA). $\mathrm{Ca}^{2+}$ concentrations were calculated using the equation $\left[\mathrm{Ca}^{2+}\right]_{i}=K_{d}\left(F_{380} \max / F_{380}\right.$ $\min )\left(R-R_{\min }\right) /\left(R_{\max }-R\right)$; a $K_{d}$ value of $229 \mathrm{nM}$ was assumed for the binding of calcium to Fura-2/AM. $R_{\max }$ and $R_{\min }$ were determined in each experimental group by the consecutive addition of $30 \mu \mathrm{M}$ Triton X-100 $\left(R_{\max }\right)$ and 50 mM EGTA $\left(R_{\text {min }}\right)$.

\section{Measurement of caspase-3 activity}

To analyze caspase- 3 activity, cell pellets were resuspended in lysis buffer [25 mM HEPES (pH 7.4), 0.1 \% Triton X-100, $10 \%$ glycerol, $5 \mathrm{mM}$ DTT, and a protease inhibitor cocktail] and spun by centrifugation at $13,000 \mathrm{rpm}$ at $4{ }^{\circ} \mathrm{C}$ for $30 \mathrm{~min}$. The soluble protein fraction $(40 \mu \mathrm{g})$ was mixed with $100 \mu \mathrm{M}$ of the caspase-3-specific substrate Ac-DEVDAFC (Acetyl-Asp-Glu-Val-Asp-AFC, Sigma-Aldrich) in a final volume of $100 \mu \mathrm{L}$ and incubated at $37{ }^{\circ} \mathrm{C}$. Caspase-3 activity was analyzed continuously by monitoring fluorogenic AFC release at $37^{\circ} \mathrm{C}$. Subsequently, substrate cleavage was monitored at $405 \mathrm{~nm}$ using a SPECTRAmax 340 microplate reader. All data were analyzed using SOFTmax PRO software (Molecular Devices, Sunnyvale, CA, USA).

\section{Measurement of caspase-12 activity}

Caspase-12 activity was measured spectrophotometrically by detecting free AFC cleavage with caspase12-specific substrates using a Caspase-12 Assay Kit (Biovision, San Francisco, CA, USA). After the lysates were incubated with ATAD-AFC (AFC: 7-amino-4-trifluoromethyl coumarin) for $2 \mathrm{~h}$ at $37^{\circ} \mathrm{C}$, the absorbance of each sample at $505 \mathrm{~nm}$ was read.

\section{NADPH oxidase activity assay}

Cells were seeded in six-well plates and cultured for $48 \mathrm{~h}$. Next, the cells were treated with $0.1 \mu \mathrm{M} \mathrm{Tg}$ for $24 \mathrm{~h}$ in the presence or absence of $100 \mu \mathrm{g} / \mathrm{mL}$ PPHs for $30 \mathrm{~min}$. NADPH oxidase activity was determined based on superoxide-induced lucigenin photoemission, as described by Rao and Maddala et al. [27]. Enzymatic assays were performed in a final volume of $0.2 \mathrm{ml}$ containing $50 \mathrm{mM}$ phosphate buffer ( $\mathrm{pH}$ 7.0), $1 \mathrm{mM}$ EGTA, $150 \mathrm{mM}$ sucrose, $0.5 \mathrm{mM}$ lucigenin, $0.1 \mathrm{mM} \mathrm{NADPH}$, and cell lysis solution. Enzymatic reactions were initiated by the addition of lucigenin. Photoemission, expressed as relative light units, was measured every minute for 10 min using a luminometer. Assays were performed in the dark at room temperature with all appropriate controls.

\section{Superoxide dismutase (SOD) activity assay}

Cells were seeded in six-well plates and cultured for $48 \mathrm{~h}$. The cells were then treated with $0.1 \mu \mathrm{M} \mathrm{Tg}$ for $24 \mathrm{~h}$ in the presence or absence of $100 \mu \mathrm{g} / \mathrm{mL}$ PPHs for $30 \mathrm{~min}$. Next, cells were harvested and the level of SOD activity was determined using a SOD assay kit (k335-100, Biovision) according to the manufacturer's instructions.

\section{DCFDA assay (ROS production)}

The cellular ROS level was measured by following the protocol described by Badham et al. (2010) [28]. Briefly, cells were treated with $0.1 \mu \mathrm{M} \mathrm{Tg}$ at $37{ }^{\circ} \mathrm{C}$ in the presence or absence of $100 \mu \mathrm{g} / \mathrm{mL}$ PPHs or $2 \mu \mathrm{M}$ BAPTA/ $\mathrm{AM}$ for $24 \mathrm{~h}$. Next, cells were incubated with $10 \mu \mathrm{M} 2$, $7^{\prime}$-dichlorofluorescein diacetate (DCFDA) at $37^{\circ} \mathrm{C}$ for an additional $30 \mathrm{~min}$. The fluorescence intensity of 2,7'dichlorofluorescein, a product of the reaction between DCFDA and cellular ROS, was analyzed using a fluorescence reader (SpectraMax 190, Molecular Devices, LLC, Sunnyvale, CA, USA).

\section{Statistical analysis}

Results are presented as means \pm SEs of $n$ cells. Paired and unpaired Student's $t$-tests were applied to the test and control conditions where appropriate. Microcal Origin software (Northampton, MA, USA) was used for all statistical calculations.

\section{Results}

PPHs alleviate Tg-induced cell death in MC3T3-E1 osteoblastic cells

Porcine placenta hydrolysates (PPHs) have traditionally been used to treat bone resorption, especially in menopausal women. Since calcium disturbance is a known mechanism of bone dysmetabolism [29], thapsigargin (a $\mathrm{Ca}^{2+}$-ATPase inhibitor and $\mathrm{Ca}^{2+}$-disturbing agent) was applied to PPHs-treated or non-treated MC3T3E-1 
osteoblastic cells. MC3T3-E1 osteoblasts were used to study the efficacy and function of PPHs on osteoblasts because these secretory cells have highly developed ER. First, we tested the effect of PPHs on cell viability. At concentrations ranging from 25 to $100 \mu \mathrm{g} / \mathrm{mL}$, PPHs did not significantly affect the viability of MC3T3-E1 osteoblastic cells (Additional file 1: Figure S1A). However, treatment of cells with $0.025,0.05$, or $0.1 \mu \mathrm{M}$ Tg for 24 h significantly increased cell death in a concentration-dependent manner (Additional file 1: Figure S1B). Interestingly, PPHs significantly blunted Tg-induced cell death in a concentrationdependent manner (Additional file 1: Figure S1C). The kinetics of PPHs-mediated protection $(100 \mu \mathrm{g} / \mathrm{mL}$ PPHs $)$ are shown in Additional file 1: Figure S1D. To investigate the mechanism of cell death, apoptosis was analyzed through Hoechst 33342 staining. Representative photomicrographs of MC3T3-E1 nuclear morphology are shown in Fig. 1a. Tg treatment induced nuclear condensation and fragmentation, both of which are characteristic of apoptosis. However, pretreatment with PPHs markedly attenuated this effect. Caspase-12 activation is known to be associated with ER stress-induced apoptosis [30]. Thus, we investigated the effect of PPHs on caspase-12 activation. We found that caspase-12 activity increased significantly after Tg treatment, whereas treatment with PPHs markedly reduced Tginduced caspase-12 activity in MC3T3-E1 cells (Fig. 1b). Similarly, Tg treatment enhanced caspase-3 activation, and this increase was blocked by PPHs treatment in MC3T3-E1 cells (Fig. 1c). Next, MC3T3-E1 cells were treated with Tg in the presence or absence of PPHs and the levels of various apoptosis-related proteins (caspase-12, -3, Bax, and Bcl-2) were analyzed by immunoblotting. These experiments showed that $\mathrm{Tg}$ significantly increased the protein levels of caspase-12, caspase-3, Bax, and Bcl-2 in a timedependent manner. Interestingly, combined treatment with PPHs and $\mathrm{Tg}$ resulted in less increased protein levels of caspase-12, caspase-3, and Bax in MC3T3-E1 cells, rather than further increasing the protein level of Bcl-2, an antiapoptotic protein. This is an interesting finding because it contrasts with the results obtained with treatment with $\mathrm{Tg}$ alone (Fig. 1d). These findings suggest that PPHs protect osteoblasts against $\mathrm{Ca}^{2+}$ stress.

\section{PPHs protect against ER stress-induced apoptosis in} MC3T3-E1 osteoblastic cells

$\mathrm{Ca}^{2+}$ disturbance is linked to intra-ER $\mathrm{Ca}^{2+}$ depletion/alteration, which also affects the ER folding machinery that induce ER stress ${ }^{6-8}$. To investigate the effect of PPHs on ER stress in osteoblasts, MC3T3-E1 osteoblasts were incubated with $0.1 \mu \mathrm{M}$ Tg to induce ER stress. To confirm induction of the ER stress response, we evaluated the expression and phosphorylation status of glucose response protein 78 (GRP78), which is a representative chaperone protein, and C/EBP homologous protein ( $\mathrm{CHOP})$, which is a proapoptotic ER stress protein. We also assessed the expression and phosphorylation status of PKR-like ER kinase (p-PERK) and its downstream target eukaryotic initiation factor 2 alpha (eIF2 $\alpha$ ), which are related to protein translation attenuation, inositol-requiring enzyme 1 (IRE1- $\alpha$ ), which has an endonuclease domain and a transautophosphorylation kinase domain, and activating transcription factor 6 (ATF6 $\alpha$ ), which is a transcription factor that activates the transcription of ER molecules. The levels of all these proteins were significantly increased in cells treated with Tg. However, treatment with PPHs inhibited the Tg-mediated increases in the levels of GRP78, CHOP, p-PERK, p-eIF2 $\alpha$, p-IRE1- $\alpha$, and ATF6- $\alpha$ (Fig. 2a and b), indicating that PPHs affect the regulation of ER stress in the presence of $\mathrm{Ca}^{2+}$ disturbances.

\section{PPHs regulate calcium release and ER stress-mediated apoptosis in MC3T3-E1 osteoblastic cells}

Homeostasis of intracellular $\mathrm{Ca}^{2+}$ levels $\left(\left[\mathrm{Ca}^{2+}\right]_{\mathrm{i}}\right)$ is important for osteoblast differentiation $[29,31]$. To analyze the regulation of $\left[\mathrm{Ca}^{2+}\right]_{\mathrm{i}}$ in osteoblasts, we investigated the effects of PPHs on intracellular $\mathrm{Ca}^{2+}$ concentration. While the $\left[\mathrm{Ca}^{2+}\right]_{\mathrm{i}}$ was significantly increased in $\mathrm{Tg}$ treated cells, treatment with BAPTA/AM significantly attenuated this $\mathrm{Ca}^{2+}$ spike in Tg-treated cells (Fig. 3a). To confirm the relationship between PPHs, $\mathrm{Ca}^{2+}$, and apoptosis, Tg-treated osteoblasts were pretreated with the $\mathrm{Ca}^{2+}$-chelating agent BAPTA/AM. The effect of PPHs alone was also tested. As shown in Fig. 3b, both PPHs and BAPTA/AM protected osteoblasts against Tginduced apoptosis. Apoptosis levels were also determined by flow cytometry and expressed in units of mean fluorescence intensity. In the MC3T3-E1 cells, the apoptosis level was $27.15 \pm 1.4$ after $\mathrm{Tg}$ treatment for $24 \mathrm{~h}$, whereas the apoptosis level in the PPHs group was $15.32 \pm 2.0$. The level in the presence of $\mathrm{Ca}^{2+}$ chelating agent was similar to that in the presence of PPHs, indicating that PPHs at least partly regulates $\mathrm{Ca}^{2+}$-associated ROS production in the $\mathrm{Ca}^{2+}$ disturbing stress (Fig. 3c). Consistently, both agents also significantly blocked $\mathrm{Tg}$ induced caspase-12 and -3 activation (Fig. 3d and e), suggesting that $\mathrm{PPHs}$ protect osteoblasts from apoptosis by modulating the levels of $\mathrm{Ca}^{2+}$.

\section{PPHs regulate ROS production, NADPH oxidase activity and SOD activity in MC3T3-E1 osteoblastic cells}

To analyze the relationship of $\mathrm{Ca}^{2+}$ with $\mathrm{ROS}$ in the presence of PPHs, we determined the effect of PPHs on Tg-induced ROS release. As expected, treatment with $0.1 \mu \mathrm{M}$ Tg resulted in significantly increased ROS production. However, exposure to $100 \mu \mathrm{g} / \mathrm{mL}$ PPHs significantly attenuated ROS production in the Tg-treated MC3T3-E1 cells (Fig. 4a). 
a

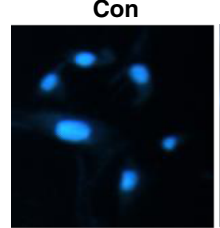

$\mathrm{Tg}+\mathrm{PPH}$

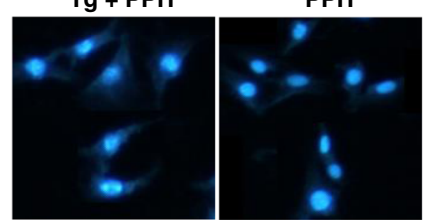

b

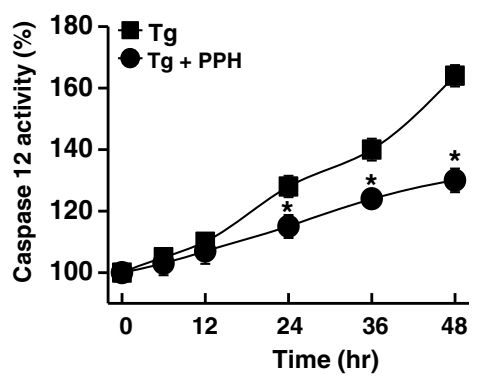

$\operatorname{Tg}$

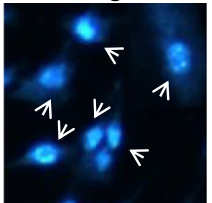

PPH

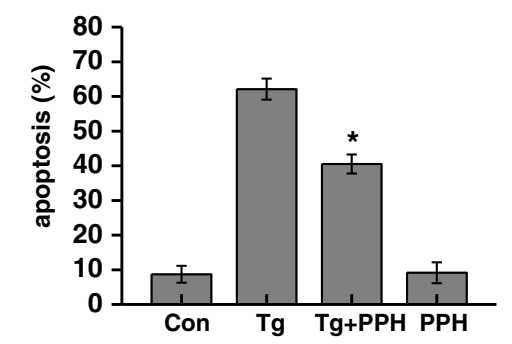

C

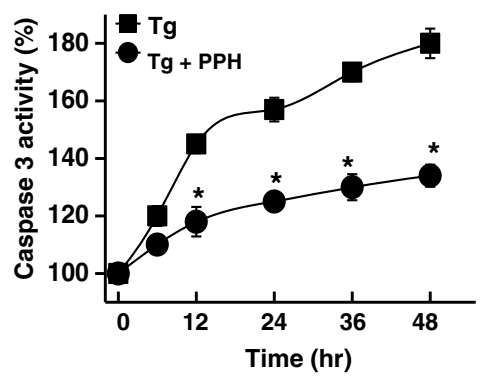

d $\mathrm{Tg}+\mathrm{PPH}$
$12 \quad 24 \quad 48$
$(\mathrm{hr})$

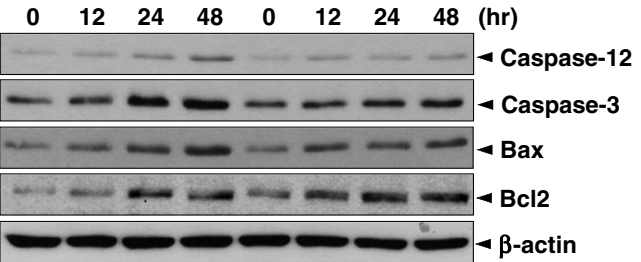

Fig. 1 PPHs protect against Tg-induced apoptosis in MC3T3-E1 osteoblastic cells. a Hoechst 33342 staining was performed in cells treated with $0.1 \mu \mathrm{M} \mathrm{Tg}$ in the presence or absence of $100 \mathrm{\mu g} / \mathrm{mL}$ PPHs for $24 \mathrm{~h}$. Arrows identify cells with condensed or fragmented nuclei characteristic of apoptosis. Apoptotic cells were quantified based on nuclear condensation or fragmentation (right). Caspase-12 (b) and -3 activities (c) were analyzed in MC3T3-E1 cells treated with $0.1 \mu \mathrm{M}$ Tg in the presence or absence of $100 \mu \mathrm{g} / \mathrm{mL}$ PPHs for $0,12,24,36$, or $48 \mathrm{~h}$. d Cells were treated with $0.1 \mu \mathrm{M}$ Tg in the presence or absence of $100 \mu \mathrm{g} / \mathrm{mL}$ PPHs for 0, 12, 24, or $48 \mathrm{~h}$. Immunoblotting was performed with antibodies against caspase-12, caspase-3, $\mathrm{Bax}, \mathrm{BCl} 2$, and $\beta$-actin. ${ }^{*} p<0.05$, significantly different from the Tg-treated condition. Tg, thapsigargin; PPHs, porcine placenta hydrolysates

Next, we examined the effect of PPHs on the activity of NADPH oxidase, an enzyme that produces ROS. As shown in Fig. 4b, PPHs and BAPTA/AM attenuated Tginduced NADPH oxidase activity. Consistently, Tg significantly suppressed the activity of SOD, a representative antioxidative enzyme that eliminates superoxides. This effect was also attenuated by PPHs and $\mathrm{Ca}^{2+}$ chelation (Fig. 4c). These findings indicate that the antioxidant effect of PPHs may contribute to their protective effects in osteoblasts, and are consistent with a model in which PPHs regulate Tg-induced elevations in $\left[\mathrm{Ca}^{2+}\right]_{\mathrm{i}}$ and subsequent ROS production in osteoblastic cells.

\section{Discussion}

In this study, we found that PPHs inhibit $\mathrm{Ca}^{2+}$ disturbancerelated osteoblast death. The basic mechanisms underlying this inhibition include the regulation of $\mathrm{Ca}^{2+}$, oxidative stress, and ER stress. We suggest that PPHs contribute to osteoblast-based endocrinal balance, implying that PPHs could potentially be used as therapeutic agents to control bone dysmetabolism.

This study showed that PPHs inhibit the cellular responses triggered by $\mathrm{Ca}^{2+}$ disturbance and ER stress, thereby protecting osteoblasts from apoptosis. ER stress has been reported to be involved in apoptosis during various pathophysiological processes, including osteoporosis $[11,12,29]$. ER stress pathways are generally activated in response to various stress conditions, such as the accumulation of misfolded proteins, disturbances of $\mathrm{Ca}^{2+}$ homeostasis, and disturbances in energy metabolism $[6,7]$. As shown in Figs. 1 and 2, Tg-induced cell death and ER stress were inhibited in PPHs-treated osteoblasts. Our 


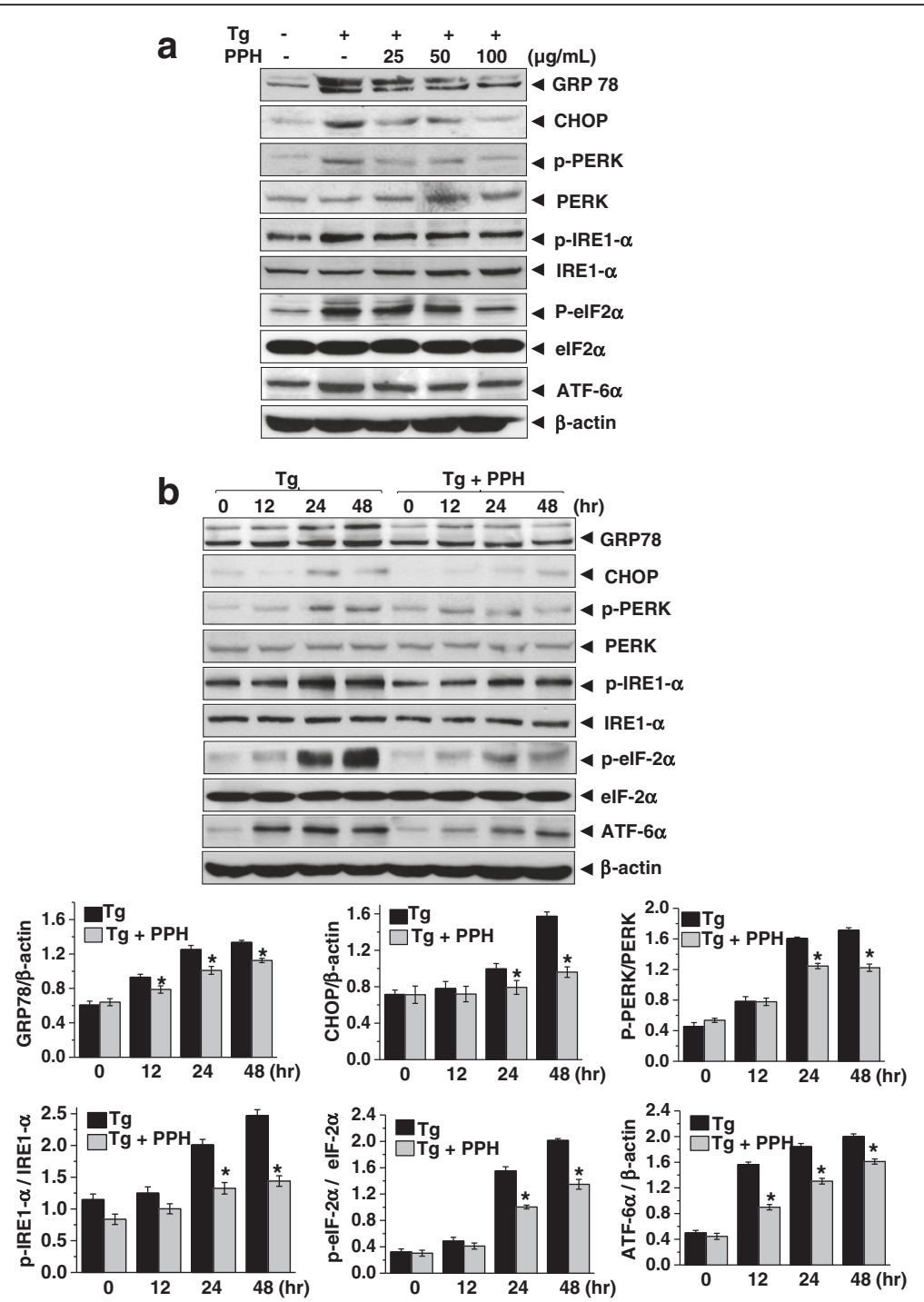

Fig. 2 PPHs regulate Tg-induced ER stress response in MC3T3-E1 osteoblastic cells. a MC3T3-E1 cells were treated with $0.1 \mu M$ Tg in the presence or absence of 25,50 , or $100 \mathrm{\mu g} / \mathrm{mL}$ PPHs for $24 \mathrm{~h}$. Immunoblotting was performed using antibodies against GRP78, CHOP, p-PERK, PERK, p-IRE1a, IRE1a, p-elF2a, elF2a, ATF6a, and $\beta$-actin. b Cells were treated with $0.1 \mu \mathrm{M} \mathrm{Tg}$ in the presence or absence of $100 \mu \mathrm{g} / \mathrm{mL}$ PPHs for $0,12,24$, or $48 \mathrm{~h}$. Immunoblotting was performed with antibodies against GRP78, CHOP, p-PERK, PERK, p-IRE1a, IRE1a, p-elF2a, elF2a, ATF6a, and $\beta$-actin. . $p<$ 0.05, significantly different from the Tg-treated condition. Tg, thapsigargin; PPHs, porcine placenta hydrolysates

results suggest that PPHs act by inhibiting $\mathrm{Ca}^{2+}$ release (Fig. 3a). Both $\mathrm{Ca}^{2+}$ disturbance and ER stress have been implicated in the pathogenesis of osteoporosis [11, 12, 29]. $\mathrm{Ca}^{2+}$ is an essential intracellular signaling molecule involved in the regulation of numerous cellular processes, including cell proliferation, differentiation, morphology, and function [32]. The intracellular $\mathrm{Ca}^{2+}$ concentration can be significantly increased via $\mathrm{Ca}^{2+}$ influx from the extracellular space or by $\mathrm{Ca}^{2+}$ release from the ER [33]. The release of $\mathrm{Ca}^{2+}$ from the ER is mainly regulated by the inositol trisphosphate 3 (IP3) receptors (IP3Rs) and the ryanodine receptors (RyRs) [7]. Moreover, $\mathrm{Ca}^{2+}$-activated signaling pathways have been demonstrated to regulate osteoblast proliferation and differentiation [27]. In addition, $\mathrm{Ca}^{2+}$ is also involved in the synthesis, folding, and post-translational modifications of proteins in the ER. Disturbance of the $\mathrm{Ca}^{2+}$ balance activates the unfolded protein response (UPR) in an attempt to restore homeostasis [34]. The UPR signaling axis, which includes GRP78, CHOP, p-IRE- $1 \alpha$, p-PERK, p-eIF $2 \alpha$, and ATF- $6 \alpha$ was highly activated under $\mathrm{Ca}^{2+}$ stress, whereas PPHs attenuated the UPR (Fig. 2a, b). Usually, unfolded protein stress in the ER (ER stress) activates the ATF6, IRE-1 $\alpha$, and PERK branches of the UPR. This activation, in turn, regulates the expression of target genes involved in the modulation of ER protein folding, such as GRP78 and 

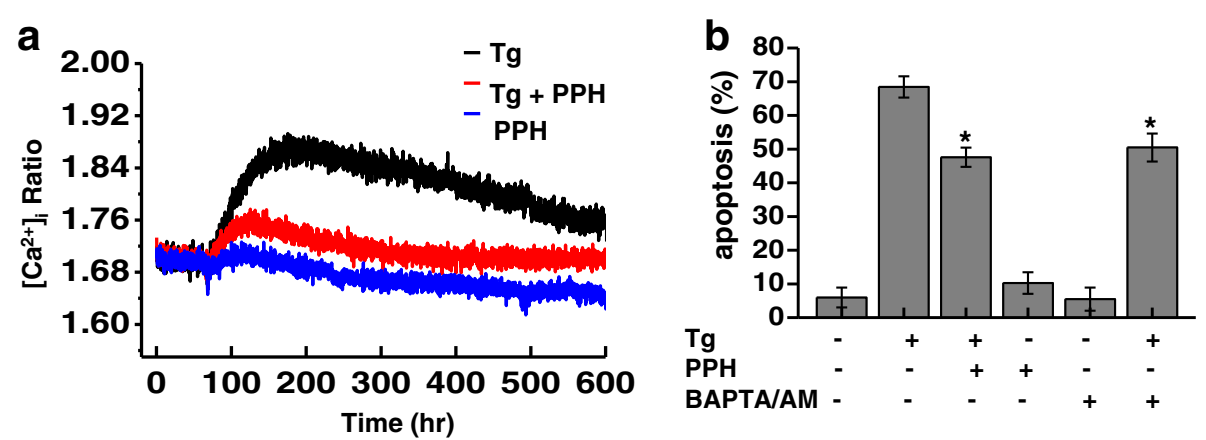

C
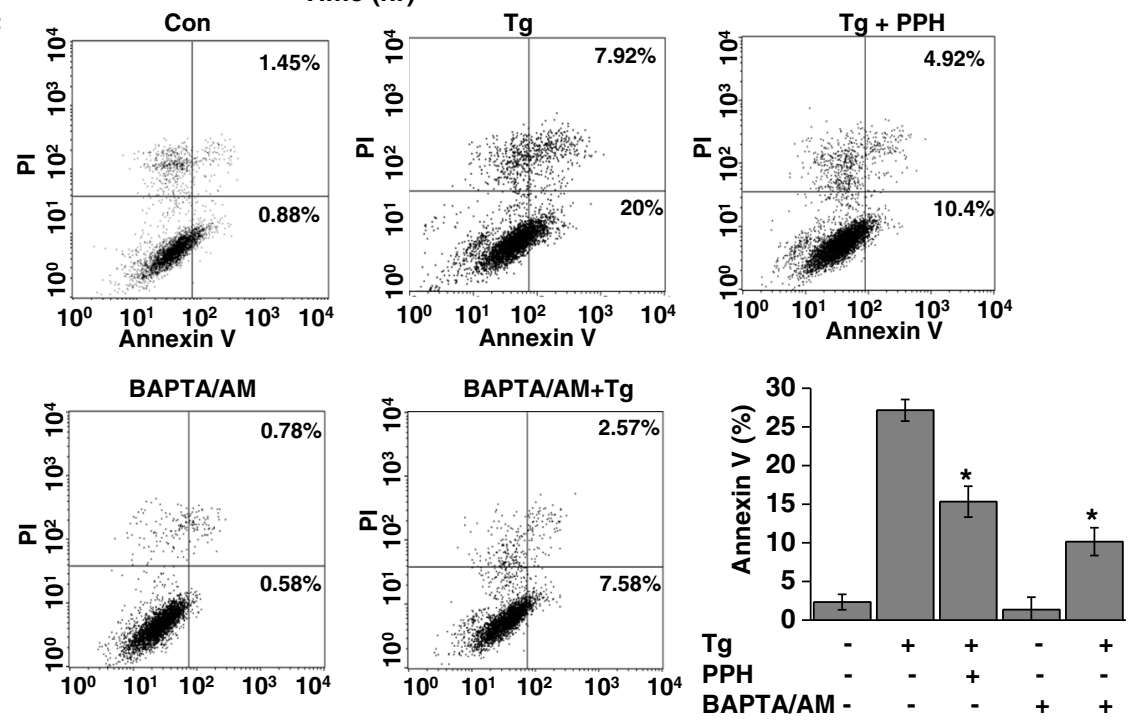

d

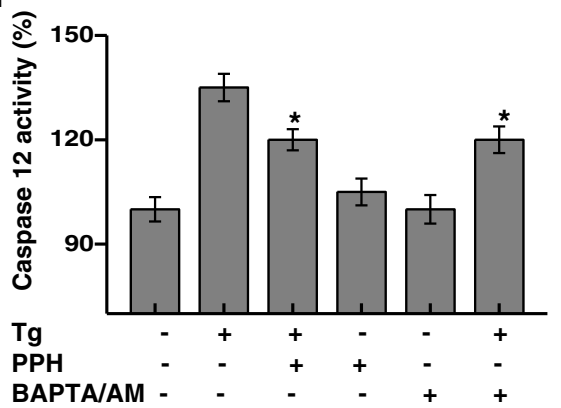

e

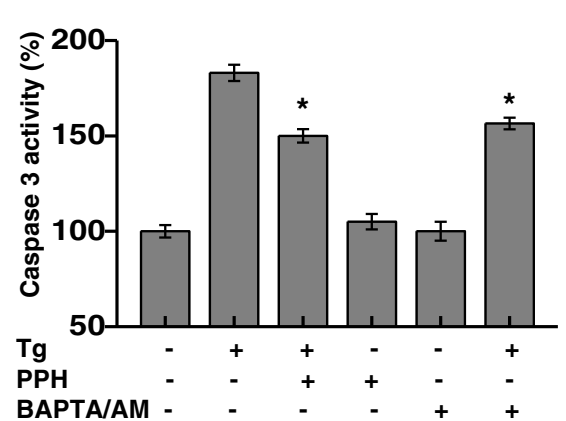

Fig. 3 PPHs regulate ER calcium disturbance and apoptosis. a Cells were treated with $0.1 \mu \mathrm{M} \mathrm{Tg}$ (black) for $24 \mathrm{~h}$ in the presence or absence of $100 \mu \mathrm{g} / \mathrm{mL}$ PPHs (red), or PPHs alone (blue), and then loaded with $2 \mu \mathrm{M}$ Fura-2/AM for $30 \mathrm{~min}$ at $37^{\circ} \mathrm{C}$. The fluorescence intensity of Fura-2/AM was then measured as described in Materials and Methods. $\mathbf{b}$ to $(\mathbf{d})$ Cells were treated with $0.1 \mu \mathrm{M}$ Tg for $24 \mathrm{~h}$ in the presence or absence of $2 \mu \mathrm{M}$ BAPTA/AM or $100 \mu \mathrm{g} / \mathrm{mL}$ PPHs for $30 \mathrm{~min}$. Apoptosis (b) was quantified based on nuclear condensation and fragmentation. Cells were stained with FITC-conjugated Annexin V and PI, followed by flow cytometric analysis (c). Caspase-12 (d) and -3 (e) activities were analyzed as described in Materials and Methods. ${ }^{*} p<0.05$, significantly different from the Tg-treated condition. Tg, thapsigargin; PPHs, porcine placenta hydrolysates

XBP1 [35]. Mild ER stress has been demonstrated to aid osteoblast differentiation [36]. However, if the stress is prolonged and unmitigated, the UPR switches to initiate cell apoptosis $[19,37]$. Persistent stress in osteoblasts that leads to apoptosis and affects communication with other bone cells is also considered to be ER stress. $\mathrm{Ca}^{2+}$ stress seems to be more related with persistent/prolonged stress conditions, whereas PPHs regulate the ER stress response.
The in vitro analyses presented here indicate that PPHs contribute to $\mathrm{Ca}^{2+}$ maintenance in osteoblasts, leading to ER stress regulation and cell protection. Additionally, we showed that the ER redox balance explains the association with $\mathrm{Ca}^{2+}$ disturbance. In studies of $\mathrm{Ca}^{2+}$ homeostasis imbalance, ER stress has been highly linked with ER stressassociated ROS [38]. In this study, we hypothesized that ROS might be generated from $\mathrm{Ca}^{2+}$ disturbances resulting 

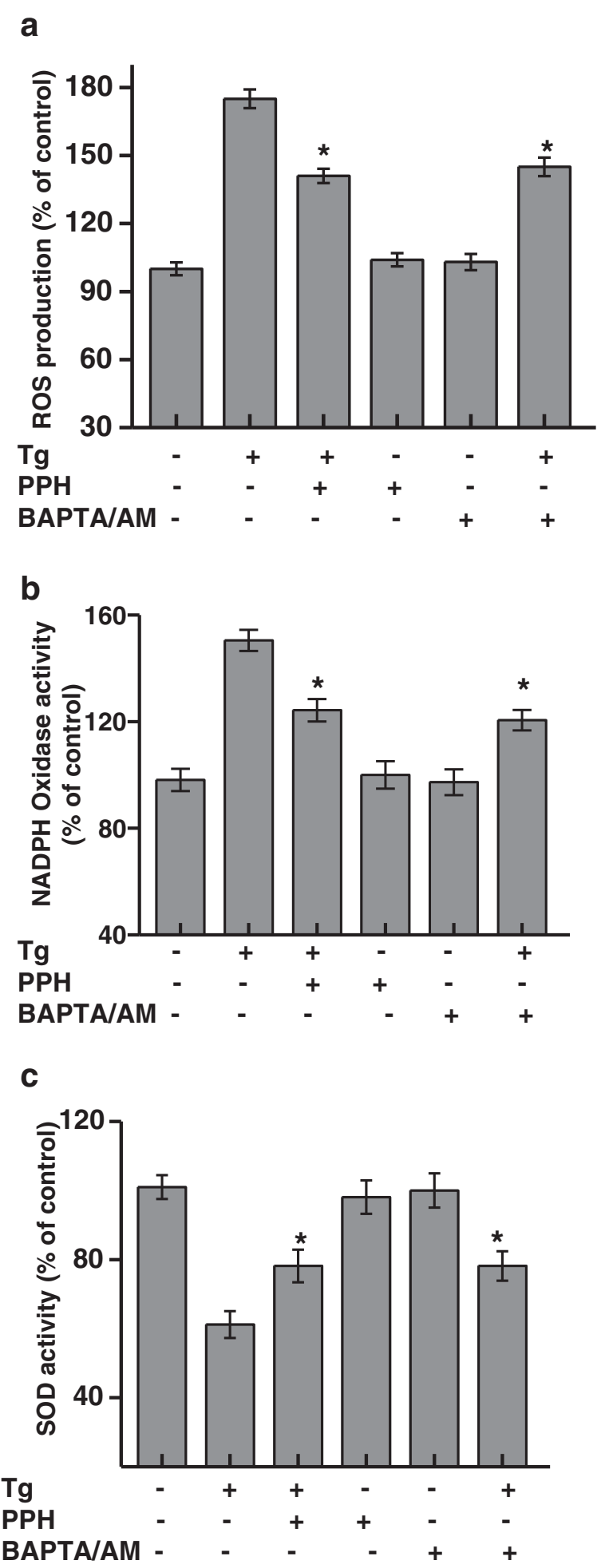

Fig. 4 PPHs regulate ROS production, NADPH oxidase activity, and SOD activity in MC3T3-E1 osteoblastic cells. MC3T3-E1 cells were treated with $0.1 \mu \mathrm{M} \mathrm{Tg}$ for $24 \mathrm{~h}$ in the presence or absence of $2 \mu \mathrm{M}$ BAPTA/AM or $100 \mu \mathrm{g} / \mathrm{mL}$ PPHs for $30 \mathrm{~min}$. ROS production was assessed by DCFDA staining (a) as described in Materials and Methods. NADPH oxidase (b) and SOD activity (c) were analyzed. ${ }^{*} p$ $<0.05$, significantly different from the Tg-treated condition. Tg, thapsigargin; PPHs, porcine placenta hydrolysates

from Tg-induced ER stress. As expected, treatment with Tg increased ROS levels (Fig. 4a). However, the intracellular ROS content was significantly decreased in PPHstreated osteoblasts compared with Tg-treated osteoblasts. The relationship between ER-induced oxidative stress and $\mathrm{Ca}^{2+}$ disturbance has been investigated [38]. $\mathrm{Ca}^{2+}$ can be a combined physiological and pathological effector. Moreover, ROS are generated by various environmental agents as well as during normal cellular metabolism. ROS play a major role in the pathogenesis of various diseases, including osteoporosis [39]. Osteoporosis is characterized by reduced bone mass resulting from an imbalance between bone formation by osteoblasts and bone resorption by osteoclasts. Since the rate of osteoblast apoptosis regulates bone formation [1, 2, 40,41], the effect of PPHs on ROS may yield a protective effect that inhibits osteoporosis.

In this study, we found that PPHs regulate bone metabolism disturbances in osteoblasts by controlling $\mathrm{Ca}^{2+}$ concentrations, thereby also affecting related ER stress and ROS. Since PPHs do not include ovarian hormones, this regulatory effect on bone metabolism disturbance is not associated with ovarian hormones such as estrogen. Thus, improvements in the amino acid profiles of PPHs should be considered, as should the presence of modified amino acids. Nutrients and trace minerals, including essential amino acids such as arginine, lysine, vitamin $\mathrm{K}$, $\mathrm{Mn}, \mathrm{B}$, vitamin $\mathrm{D}, \mathrm{Zn}, \mathrm{Cu}$, folate, and $\mathrm{Si}$ are often used to improve bone structure [42]. Dietary arginine and lysine are also believed to play important roles in bone development, growth, and modeling [42, 43]. Arginine is involved in both the synthesis of substrates (polyamine and L-Pro) implicated in collagen synthesis and in the production of growth hormones, including insulin-like growth factor-I [44]. In addition, arginine is thought to alleviate metabolic disturbances in $\mathrm{Ca}^{2+}$ absorption, growth, and ossification defects [45]. PPHs contain large amounts of arginine and essential amino acids. Thus, since PPHs contain arginine and other essential amino acids, they may be useful preventive or therapeutic agents against osteoporosis.

\section{Conclusions}

This study suggests that PPHs protect bone-forming MC3T3-E1 osteoblasts against $\mathrm{Ca}^{2+}$ stress. In addition, PPHs regulate $\mathrm{Ca}^{2+}$ release and the related ROS and ER 
stress responses. Our data also indicate that PPHs are a new ER stress regulator, at least in bone-forming osteoblasts. The insights from this in vitro study have implications on our understanding of the mechanism by which PPHs might exert therapeutic effects against bone disturbance.

\section{Additional file}

Additional file 1: Figure S1. Protective effects of PPHs on Tg-induced cell death in MC3T3-E1 osteoblastic cells (PDF 119 KB)

\section{Abbreviations}

ER, endoplasmic reticulum, PPHs, porcine placenta hydrolysates, ROS, reactive oxygen species, $\mathrm{Tg}$, thapsigargin

\section{Acknowledgments}

This study was supported by Chonbuk National University Hospital (JHK) and the National Research Foundation (2015R1A2A1A13001849). This study was also supported by CODEBIO CO., LTD.

\section{Availability of data and materials}

All datasets supporting the conclusions of this article are included within the article

\section{Author contributions}

HYL, HRK, and SYP participated in the design of the research. HYL and HJC carried out the experiments, analyzed the data, and wrote the paper. JHK provided funding and supervised the study. All authors read and approved the final manuscript.

\section{Competing interests}

The authors declare that they have no competing interest.

\section{Consent for publication}

Not applicable.

\section{Ethics approval and consent to participate} Not applicable.

\section{Author details \\ 'Department of Pharmacology and New Drug Development Institute, Medical School, Chonbuk National University, Jeonju 560-182, Republic of Korea. ${ }^{2}$ Department of Dental Pharmacology, College of Dentistry, Wonkwang University, Iksan 570-749, Republic of Korea. ${ }^{3}$ CODEBIO CO., LTD, Busong 1 gil 62, Jiksan-eup, Seobuk-gu, Cheonan, Chungnam 331-815, Republic of Korea. ${ }^{4}$ Department of Obstetrics and Gynecology, Institute for Medical Sciences, Chonbuk National University Medical School, Jeonju 560-182, Republic of Korea.}

Received: 21 February 2016 Accepted: 7 July 2016

Published online: 25 July 2016

\section{References}

1. Karsenty G, Wagner EF. Reaching a genetic and molecular understanding of skeletal development. Dev Cell. 2002;2(4):389-406.

2. Raisz LG. Pathogenesis of osteoporosis: concepts, conflicts, and prospects. J Clin Investig. 2005;115(12):3318-25.

3. Wu Y, Yang M, Fan J, Peng Y, Deng L, Ding Y, Yang R, Zhou J, Miao D, Fu Q. Deficiency of osteoblastic Arl6ip5 impaired osteoblast differentiation and enhanced osteoclastogenesis via disturbance of ER calcium homeostasis and induction of ER stress-mediated apoptosis. Cell Death Dis. 2014;5, e1464.

4. Hock JM, Krishnan V, Onyia JE, Bidwell JP, Milas J, Stanislaus D. Osteoblast apoptosis and bone turnover. J Bone Miner Res. 2001;16(6):975-84.

5. Downey PA, Siegel MI. Bone biology and the clinical implications for osteoporosis. Phys Ther. 2006;86(1):77-91.
6. Schroder M. Endoplasmic reticulum stress responses. Cell Mol Life Sci. 2008; 65(6):862-94.

7. Boyce M, Yuan J. Cellular response to endoplasmic reticulum stress: a matter of life or death. Cell Death Differ. 2006:13(3):363-73.

8. Hotamisligil GS. Endoplasmic reticulum stress and the inflammatory basis of metabolic disease. Cell. 2010;140(6):900-17.

9. Hasnain SZ, Lourie R, Das I, Chen AC, McGuckin MA. The interplay between endoplasmic reticulum stress and inflammation. Immunol Cell Biol. 2012; 90(3):260-70.

10. Yamada H, Nakajima T, Domon H, Honda T, Yamazaki K. Endoplasmic reticulum stress response and bone loss in experimental periodontitis in mice. J Periodontal Res. 2015;50(4):500-8.

11. Park SJ, Kim KJ, Kim WU, Oh $\mathrm{H}$, Cho CS. Involvement of endoplasmic reticulum stress in homocysteine-induced apoptosis of osteoblastic cells. J Bone Miner Metabol. 2012:30(4):474-84.

12. Tang $\mathrm{CH}$, Chiu YC, Huang CF, Chen YW, Chen PC. Arsenic induces cell apoptosis in cultured osteoblasts through endoplasmic reticulum stress. Toxicol Appl Pharmacol. 2009;241(2):173-81.

13. Lisse TS, Thiele F, Fuchs H, Hans W, Przemeck GK, Abe K, Rathkolb B, Quintanilla-Martinez L, Hoelzlwimmer G, Helfrich M, et al. ER stress-mediated apoptosis in a new mouse model of osteogenesis imperfecta. PLoS Genet. 2008;4(2), e7.

14. He L, Lee J, Jang JH, Sakchaisri K, Hwang J, Cha-Molstad HJ, Kim KA, Ryoo IJ, Lee HG, Kim SO, et al. Osteoporosis regulation by salubrinal through elF2alpha mediated differentiation of osteoclast and osteoblast. Cellular Signal. 2013; 25(2):552-60.

15. Raggatt $\amalg$, Partridge NC. Cellular and molecular mechanisms of bone remodeling. J Biol Chem. 2010;285(33):25103-8.

16. Raisz LG. Physiology and pathophysiology of bone remodeling. Clinical chemistry. 1999:45(8 Pt 2):1353-8.

17. Iurlaro $R$, Munoz-Pinedo C. Cell death induced by endoplasmic reticulum stress. FEBS J. 2015.

18. Szegezdi E, Logue SE, Gorman AM, Samali A. Mediators of endoplasmic reticulum stress-induced apoptosis. EMBO Rep. 2006;7(9):880-5.

19. Tabas I, Ron D. Integrating the mechanisms of apoptosis induced by endoplasmic reticulum stress. Nat Cell Biol. 2011;13(3):184-90.

20. Togashi S, Takahashi N, Iwama M, Watanabe S, Tamagawa K, Fukui T. Antioxidative collagen-derived peptides in human-placenta extract. Placenta. 2002;23(6):497-502

21. Yamasaki M, Hasegawa S, Takahashi H, Kobayashi Y, Sakai C, Ashizawa Y, Asai Y, Kanzaki M, Fukui T. Placental extracts induce the expression of antioxidant enzyme genes and suppress melanogenesis in B16 melanoma cells. Natur Prod Res. 2015;29(22):2103-6.

22. Hong JW, Lee WJ, Hahn SB, Kim BJ, Lew DH. The effect of human placenta extract in a wound healing model. Ann Plast Surg. 2010;65(1):96-100.

23. Nath $S$, Bhattacharyya D. Cell adhesion by aqueous extract of human placenta used as wound healer. Indian J Exp Biol. 2007:45(8):732-8.

24. Fang XP, Xia WS, Sheng QH, Wang YL. Purification and characterization of an immunomodulatory Peptide from bovine placenta water-soluble extract. Prep Biochem Biotechnol. 2007;37(3):173-84.

25. Lee KH, Park HJ, Seo HG, Kim JH, Lim GS, Lee WY, Kim NH, Kim JH, Lee JH, Jung $\mathrm{HS}$, et al. Immune modulation effect of porcine placenta extracts in weaned the pig. J Anim Sci. 2013:91(5):2405-13.

26. Kim HR, Lee GH, Ha KC, Ahn T, Moon JY, Lee BJ, Cho SG, Kim S, Seo YR, Shin YJ, et al. Bax Inhibitor-1 is a pH-dependent regulator of $\mathrm{Ca} 2+$ channel activity in the endoplasmic reticulum. J Biol Chem. 2008;283(23):15946-55.

27. Zayzafoon M. Calcium/calmodulin signaling controls osteoblast growth and differentiation. J Cell Biochem. 2006;97(1):56-70.

28. Badham HJ, LeBrun DP, Rutter A, Winn LM. Transplacental benzene exposure increases tumor incidence in mouse offspring: possible role of fetal benzene metabolism. Carcinogenesis. 2010;31(6):1142-8.

29. Hino S, Kondo S, Yoshinaga K, Saito A, Murakami T, Kanemoto S, Sekiya H, Chihara K, Aikawa Y, Hara H, et al. Regulation of ER molecular chaperone prevents bone loss in a murine model for osteoporosis. J Bone Miner Metabol. 2010;28(2):131-8.

30. Nakagawa T, Zhu H, Morishima N, Li E, Xu J, Yankner BA, Yuan J. Caspase-12 mediates endoplasmic-reticulum-specific apoptosis and cytotoxicity by amyloid-beta. Nature. 2000:403(6765):98-103.

31. Ishikawa M, Iwamoto T, Nakamura T, Doyle A, Fukumoto S, Yamada Y. Pannexin 3 functions as an ER Ca(2+) channel, hemichannel, and gap junction to promote osteoblast differentiation. J Cell Biol. 2011;193(7):1257-74. 
32. Cui W, Ma J, Wang X, Yang W, Zhang J, Ji Q. Free fatty acid induces endoplasmic reticulum stress and apoptosis of beta-cells by $\mathrm{Ca} 2+/$ calpain-2 pathways. PloS One. 2013;8(3), e59921.

33. Berridge MJ, Lipp P, Bootman MD. The versatility and universality of calcium signalling. Nat Rev Mol Cell Biol. 2000;1 (1):11-21.

34. Mekahli D, Bultynck G, Parys JB, De Smedt H, Missiaen L. Endoplasmic-reticulum calcium depletion and disease. Cold Spring Harb Perspect Biol. 2011;3(6):a004317.

35. Walter $\mathrm{P}$, Ron $\mathrm{D}$. The unfolded protein response: from stress pathway to homeostatic regulation. Science. 2011;334(6059):1081-6.

36. Saito A, Ochiai K, Kondo S, Tsumagari K, Murakami T, Cavener DR, Imaizumi K. Endoplasmic reticulum stress response mediated by the PERK-elF2(alpha)ATF4 pathway is involved in osteoblast differentiation induced by BMP2. J Biol Chem. 2011;286(6):4809-18.

37. Hetz C. The unfolded protein response: controlling cell fate decisions under ER stress and beyond. Nat Rev Mol Cell Biol. 2012;13(2):89-102.

38. Liu H, Bowes 3rd RC, van de Water B, Sillence C, Nagelkerke JF, Stevens JL. Endoplasmic reticulum chaperones GRP78 and calreticulin prevent oxidative stress, Ca2+ disturbances, and cell death in renal epithelial cells. J Biol Chem. 1997;272(35):21751-9.

39. Finkel T, Holbrook NJ. Oxidants, oxidative stress and the biology of ageing Nature. 2000;408(6809):239-47.

40. Rodan GA, Martin TJ. Therapeutic approaches to bone diseases. Science. 2000;289(5484):1508-14.

41. Weinstein RS, Manolagas SC. Apoptosis and osteoporosis. Am J Med. 2000 108(2):153-64.

42. Sahin K, Onderci M, Sahin N, Balci TA, Gursu MF, Juturu V, Kucuk O. Dietary arginine silicate inositol complex improves bone mineralization in quail. Poult Sci. 2006;85(3):486-92.

43. Civitelli R, Villareal DT, Agnusdei D, Nardi P, Avioli LV, Gennari C. Dietary Llysine and calcium metabolism in humans. Nutrition. 1992;8(6):400-5.

44. Chevalley T, Rizzoli R, Manen D, Caverzasio J, Bonjour JP. Arginine increases insulin-like growth factor-l production and collagen synthesis in osteoblastlike cells. Bone. 1998:23(2):103-9.

45. Fiore CE, Pennisi P, Cutuli VM, Prato A, Messina R, Clementi G. L-arginine prevents bone loss and bone collagen breakdown in cyclosporin A-treated rats. Eur J Pharmacol. 2000;408(3):323-6.

\section{Submit your next manuscript to BioMed Central and we will help you at every step:}

- We accept pre-submission inquiries

- Our selector tool helps you to find the most relevant journal

- We provide round the clock customer support

- Convenient online submission

- Thorough peer review

- Inclusion in PubMed and all major indexing services

- Maximum visibility for your research

Submit your manuscript at www.biomedcentral.com/submit

C) Biomed Central 